\title{
高水圧作用下におけるコンクリートの 破壊挙動に関する基礎的研究
}

\author{
堀 尚 1 - 千夕和 伸浩 2 - 岩波 光保 3 \\ 1 学生会員 東京工業大学 工学部 土木・環境工学科（干152-8552 東京都目黒区大岡山 2-12-1） \\ E-mail: hori.t.af@m.titech.ac.jp \\ 2 正会員 東京工業大学大学院 助教（干152-8552 東京都目黒区大岡山 2-12-1） \\ E-mail: chijiwa@cv.titech.ac.jp \\ 3 正会員 東京工業大学大学院 教授（干152-8552 東京都目黒区大岡山 2-12-1）
}

\begin{abstract}
近年，注目の集まる海底資源の開発において深海構造物へのコンクリートの適用性を探るための基礎 研究として, 深海並みの高水圧が作用した場合のセメント硬化体の破壊挙動の進展や機構の把握を試み た。 セメントペーストによる破壊形状の比較から水セメント比と空気量の差異が破壊の進展の度合いに 影響を及ぼすことが示唆された。モルタルによる体積ひずみの時間変化の測定から, 空気量の差異が体 積ひずみの収縮側への増加量に影響を及ぼすことが示唆されたと共に, 高水圧下で長時間静置した後, 体積ひずみ変化が膨張側に転じる傾向があることが推察された。
\end{abstract}

Key Words : concrete, high water pressure, water penetration, void structure, pore water pressure

\section{1. はじめに}

近年，日本近海の海底からはレアアースやメタンハイ ドレートといった希少資源の発見が相次いでおり，これ ら海底資源は，エネルギーや鉱物資源を安定的に供給す る方策の一つとして関心を集めている．海底資源を開発 するに当たっては, 海底油田の開発に用いられるような 洋上プラットフォームを建設することが一般的であり， 海底資源の商業化に向けた中長期的な目標の一つとして 実証プラントの建設・試験が挙げられている1).

コンクリートは，その耐久性や経済性から洋上プラッ トフォームの基礎部等の材料の候補に挙げられている. 洋上プラットフォームの材料として用いるに当たって, コンクリートは深海底という維持管理が困難な環境下で 高水圧に長期間耐えなければならない.

コンクリートに水圧が作用する場合についての力学的 性状に関する研究は世界で既になされており，近年では 日本でも関心を集めている. 木村らは0.0 MPa, 0.5 MPa, $1.0 \mathrm{MPa}$ の静水圧下に24 時間静置したコンクリート供試 体と0 時間静置したコンクリート供試体を用いた各水圧 下での圧縮強度試験と引張強度試験から, 長期静置した 供試体は短期静置した供試体に比べ各強度が低下するこ とを発見した2)。齊藤らは側圧 $0.5 \mathrm{MPa}$ 及び1.0 MPa，載荷 応力4.53 $\mathrm{MPa}$ 及び9.06 $\mathrm{MPa}$ の三軸応力状態下において供
試体内部の間隙水圧とクリープひずみを測定する実験か ら，外力によってコンクリート内部に間隙水圧勾配が生 じ，間隙水圧勾配が駆動力となることで水分移動とそれ に伴うクリープひずみが発生することを確認した ${ }^{3)}$. 井之 上らは円柱供試体の側面に一定水圧を作用させる実験か らコンクリート内部の水分移動により発生するクリープ ひずみはコンクリートを破壊に至らせるということを確 認した。 井之上らはまた，水の浸透を排した状況で同様 の実験を行い，外部からの水分浸透がなければ，間隙水 圧は発生せず，破壊にも至らないことを確認した4).

日本近海で発見された海底資源は最大で水深5000 mの 深さに存在していることが分かっている5). 水深5000 mに おける水圧はおよそ50MPaであり，この水圧は一般的な コンクリートの一軸圧縮強度をはるかに上回る. 水の存 在しない三軸圧縮状態下では，コンクリートは，側圧に よる横拘束により軸圧縮時のポアソン効果による周方向 への膨張が拘束されることで，高い一軸圧縮強度を発現 することが知られているが，水圧作用下では，内部に浸 透した水による間隙水圧によってコンクリートが膨張す ることで，拘束圧に抵抗し，圧縮強度の発現が生じにく いことが推察されている2). 既往の研究結果2), 3), 4)から, 海底資源の存在する水深に対して比較的浅い水深に相当 する10 MPaに満たない水圧作用下でもコンクリートの 力学的挙動には外部からの水分浸透とコンクリート内部 
での水分移動が大きな影響を及ぼしていることが推察さ れる，そのため，水圧作用下では水の浸透，コンクリー 卜内部での水分移動，間隙水圧の発生といった点で一般 的な三軸圧縮状態とは異なると考えられる.

本研究では海底資源の存在寸る最大水深5000 mの水圧 $50 \mathrm{MPa}$ をメント硬化体に作用させることで高水圧作 用下での破壊挙動を検証すると共に，水セメント比や空 気量の差による影響といった物性の影響の観点にも着目 し，今後，コンクリートへの水圧作用を研究する上での 基礎的な知見の蓄積を図った。

\section{2. 破壊形状の観察}

\section{(1) 高水圧加力装置}

本研究における高水圧の作用は図-1 に示寸高水圧加 力装置を用いて行った. 高水圧加力装置は耐圧性の容器 と加圧用のポンプから構成される. 容器内に供試体を入 れて水で満たして密封し, 外部からポンプで注水するこ とで容器内の水圧を上げる仕組みになっている. 水圧は ポンプについたメーターによって確認する. 容器の蓋の 内側には外側のコードに接続される 6 本のピンコネク タが設置されており，ピンコネクタを介することで容器 内部にある供試体のひずみ等を測定できるようになって いる. 高水圧加力装置の容積から $\phi 10 \times 20 \mathrm{~cm}$ のコンク リート供試体を設置することができないため，本研究で は $\phi 5 \times 10 \mathrm{~cm}$ の供試体をセメントペーストとモルタルで 作製し，実験を行った.

\section{(2) 実験概要}

高水圧作用によるひび割れや破壊の発生の有無を観察 する実験を行った．また，浸透する水分量が水圧に因ら ないことも推測されるため, 高水圧による水分浸透の有 無を確かめる実験も行った.

\section{a) 供試体概要}

供試体はセメントペースト製のものとモルタル製のも のを作製した。 セメントは普通ポルトランドセメントを 用いた。細骨材は表乾密度 $2.61 \mathrm{~g} / \mathrm{cm}^{3}$ ，吸水率 1.98 (\%), 粗粒率 2.29 のものを用いた．混和剤として $\mathrm{AE}$ 㓮を用い た。 混和材として石灰石微粉末をセメントペースト供試 体に用いた. セメントペーストでは水セメント比と空気 量が，モルタルでは空気量がそれぞれ異なる．各供試体 パラメータを表-1 に示寸. 空気量は実験の歳にエアメー ターが故障していたため設計值を記す。供試体サイズは $\phi 5 \times 10 \mathrm{~cm}$ の円柱とした.

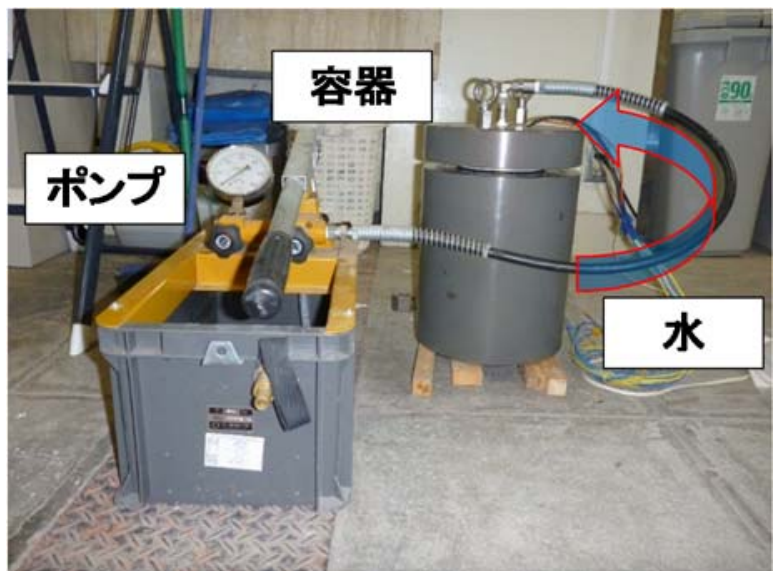

図-1 高水圧加力装置

表-1 供試体パラメータ

\begin{tabular}{|c|c|c|c|}
\hline 種類 & 名称 & W/C (\%) & 空気量 (\%) \\
\hline \multirow{2}{*}{$\begin{array}{c}\text { セメント } \\
\text { ペースト }\end{array}$} & FrP-1 & 50 & 5 \\
\cline { 2 - 4 } & FrP-2 & 50 & 10 \\
\cline { 2 - 4 } & FrP-3 & 67 & 5 \\
\hline \multirow{2}{*}{ モルタル } & FrM-1 & 50 & 5 \\
\cline { 2 - 4 } & FrM-2 & 50 & 10 \\
\hline
\end{tabular}

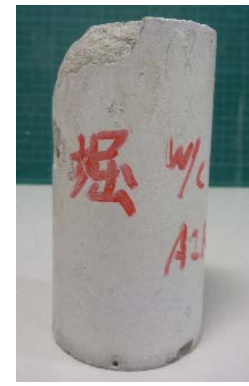

(1) FrP-1 (2 回)

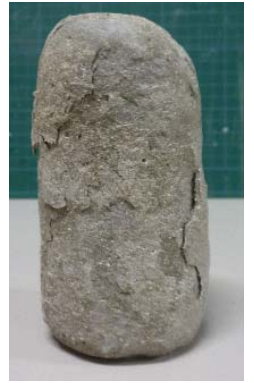

(2) FrP-2 (2 回)

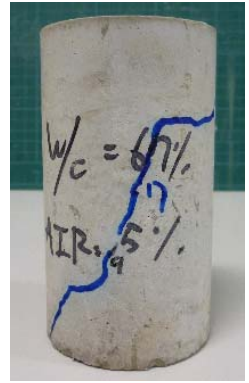

(3) FrP-3 (10 回)
図-2 セメントペーストの破壊状況

\section{b) 実験手法}

供試体を高水圧加力装置に設置し，水圧を $50 \mathrm{MPa}$ ま で加圧後, $50 \mathrm{MPa}$ で 10 分間静置し, 減圧した. 加圧時 間を 10 分としたのは齊藤らの実験 ${ }^{3)}$ から水圧作用下で の単位クリープと間隙水圧の急激な増加が止まるのが約 10 分であったためである. 本実験では加圧から減圧まで を加圧回数 1 回とした. 複数回の加圧を繰り返しても破 壊に至らない供試体は同一配合の供試体を水の張ったバ ケツに 10 分間静置し，高水圧を作用させた供試体とバ ケツの水に浸かった供試体とで加圧前後の質量を比較し, 水分浸透の有無を確かめた。

\section{(3) 実験結果}

a) セメントペースト実験結果

FrP-1 では, 1 回目の加圧後, 供試体表面に複数のひび 
割れが確認された. 2 回目の加圧後, 一部が剥落した. 剥落箇所は供試体の縁端部で, 破壊面は球面状を呈した。 2 回目の加圧終了後の供試体を図-2 に示寸.

FrP-2 では, 1 回目の加圧後, 供試体表面の広範囲にひ び割れが発生した. 2 回目の加圧後, 大量の細かい剥離 が発生した。剥離は供試体表面のほぼ全域で発生し，供 試体を楕円球状に削るように進展した. 2 回目の加圧終 了後の供試体を図-2に示寸.

FrP-3 では, 1 回目と 2 回目のいずれの加圧でも供試 体に変化は生じなかった. 7 回目の加圧後, 供試体表面 にひび割れが発生したものの, 10 回の加圧を終えても剥 離は発生しなかった. 10 回目の加圧終了後の供試体を図 -2 に示す.

FrP-1 と FrP-2 を比較すると同水セメント比下では空気 量が多いほどひび割れの発生する範囲が広いという傾向 が得られたが，これは，気泡間隔の違いによると推察さ れる. 空気量が多い場合, $\mathrm{AE}$ 剂によって供試体内に一様 に分布したエントレインドエア間の気泡間隔が狭くなる 6. 高水圧により圧入された水はひび割れを形成しつつ, 空隙中でも比較的大きな空隙であるエントレインドエア を介して浸透すると考えられ，空気量が大きく気泡間隔 の狭い場合，水分浸透によって生じるひび割れがエント レインドエアを介して連続的に繋がり，大規模なひび割 れを形成するものと推察される.

FrP-1 と FrP-3 を比較すると同空気量下では水セメント 比が大きいほどひび割れの進展が遅く, 破壊に至りにく いといら傾向が得られたが，これは，毛管空隙の量によ る透水性の違いによるものと推察される. 水セメント比 が小さく毛管空隙が少ない場合，透水性が低下し，高水 圧で圧入された水の浸透経路が少なくなるため, 浸透に 際してひび割れを形成しやすくなると考えられる. 毛細 管空隙とエントレインドエアによる気泡間隔係数はとも にコンクリートの透水性に影響を及ぼすパラメータであ るが，毛細管空隙とエントレインドエアではサイズが異 なるため, ひび割れの発生の有無や破壊の進展に対して 異なる影響をそれぞれ示したと推察される.

\section{b) モルタル実験結果}

FrM-1 では, 15 回の加圧を行っても剥離は発生しなか った.このことからモルタルはセメントペーストに比べ て高水圧による破壊に至りにくいという結果が得られた. モルタルがセメントペーストに比べて破壊に至りにくい 理由として, 細骨材が混入することにより生じる骨材周 りの遷移帯領域の影響が挙げられる．遷移帯領域を介寸 ることで水分浸透が促進されることは既往の研究 》から 報告されており, この遷移帯領域の存在が水の浸透経路 を増や寸ことで透水性が増し，高水圧による破壊の進展 が抑制されたものと推察される，そのため，粗骨材の混 入するコンクリートであってもモルタルと同様にセメン
表-2 質量変化の比較

\begin{tabular}{|c|c|c|c|}
\hline 実験環境 & 実験前(g) & 実験後(g) & $\begin{array}{c}\text { 質量変化 } \\
\text { (\%) }\end{array}$ \\
\hline \multirow{3}{*}{$50 \mathrm{MPa}$ 下 } & 384.61 & 400.28 & 4.07 \\
\cline { 2 - 4 } & 379.47 & 395.15 & 4.13 \\
\cline { 2 - 4 } & 383.83 & 398.84 & 3.90 \\
\hline \multirow{3}{*}{ バケツ内 } & 388.93 & 389.05 & 0.03 \\
\cline { 2 - 4 } & 382.36 & 382.10 & -0.07 \\
\cline { 2 - 4 } & 386.40 & 386.32 & -0.02 \\
\hline
\end{tabular}

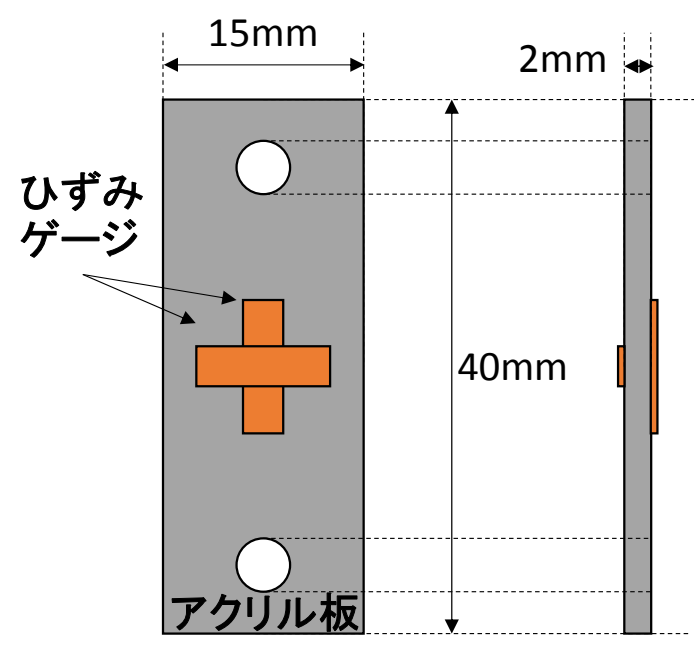

図-3 モールドゲージ模式図

トペーストと比較して高水压による破壊に至りにくいと 推察される.

FrM-2 では高水圧による水分浸透の有無を確かめる実 験を行った. 高水圧を作用させた供試体と水を張ったバ ケツに静置した供試体の質量変化を表-2 に示す. $50 \mathrm{MPa}$ の高水圧を作用させた供試体は加圧後におおよそ $4 \%$ の 質量増加を示したが，バケツに静置した供試体は質量変 化がほとんどなく, 高水圧による水分浸透が生じたこと が推察される.

\section{3. 体積ひずみ変化}

\section{(1) モールドゲージ}

本研究では，供試体内部のひずみの変化を測定するに あたりモールドゲージを自作した．高水圧加力装置内に 設置できる供試体のサイズが $\phi 5 \times 10 \mathrm{~cm}$ の円柱供試体で あるため, 一般に用いられるゲージ長 $5 \mathrm{~cm}$ のモールドゲ ージでは縦方向には埋設できるものの, 横方向には埋設 寸ることができないためである.

自作ゲージはアクリル板とひずみゲージからなる。 
クリル棒にひずみゲージを貼り付けてコンクリートに埋 設し，コンクリート内部のひずみを計測する手法は既往 の研究からその妥当性が示されている ${ }^{8)}$. 本研究ではア クリル棒をアクリル板で代用し, 縦方向と横方向にゲー ジ長 $1 \mathrm{~cm}$ のひずみゲージを貼り付けられる面積を確保 することで，1 枚のアクリル板の両面にひずみゲージを 貼り付けて縦ひずみと横ひずみを測定できるようにした. 図-3に自作モールドゲージの模式図を示す.また，アク リル板の上下の 2 箇所に穴を設けることで穴内部に充 填されたモルタルによってアクリル板と供試体の付着を 強固に得られるようにした。自作モールドゲージは使用 に際して，性能評価試験を行った。自作モールドゲージ と既存モールドゲージをそれぞれ埋設した $\phi 5 \times 10 \mathrm{~cm}$ の モルタル供試体を用いて, 繰返し載荷試験における縦ひ ずみの変化を測定した. 繰返し載荷試験では載荷応力が 最大 $5 \mathrm{MPa}$ の弾性領域内で 3 サイクル繰り返した. 繰返 し載荷試験の結果を図-4 に示寸. 図-4 から 3 サイクル の繰返し載荷試験の間, 既存ゲージと自作ゲージは共に, 弾性域での線形性を表し, 測定值もほぼ等しい結果とな った.

\section{(2) 実験概要}

2.の破壊形状の観察から高水圧下においても破壊に至 りにくいと推察されたモルタル供試体を用いて，高水圧 作用によるひずみの挙動を明らかにするため, 供試体に モールドゲージを埋設し，体積ひずみ変化を測定する実 験を行つた.

\section{a) 供試体概要}

供試体はモルタルで作製した。 セメントには普通ポル トランドセメントを用いた。細骨材には表乾密度 2.61 $\mathrm{g} / \mathrm{cm}^{3}$, 吸水率 $1.98(\%)$, 粗粒率 2.29 のものを用いた。 混 和剂として AE 剂を用いた，配合は水セメント比と空気 量を変えた. 各供試体パラメータを表-3に示す. 供試体 は各配合に対して 6 本作製し，個々の供試体に 1～6の 番号付けを行い, StA-1〜StC-6 と区別した. 供試体サイ ズは $\phi 5 \times 10 \mathrm{~cm}$ の円柱とした.

\section{b) 実験手法}

モールドゲージを埋設した供試体を打設し, 硬化後, 真空ポンプを用いて脱気を行った. 脱気を行うのは初期 の空隙の飽和度の差異が実験結果に影響を及ぼさないよ うにするためである．脱気を終えた供試体は外気に触れ ないよう水中に静置したまま高水圧加力装置に設置した。 高水圧加力装置に設置した後, 水圧を $50 \mathrm{MPa}$ ま加圧 後, $50 \mathrm{MPa}$ で 1 時間静置した. 水圧作用中の供試体の縦 ひずみと横ひずみを測定し，体積ひずみを算出した。体 積ひずみの算出には式(1)を用いた。

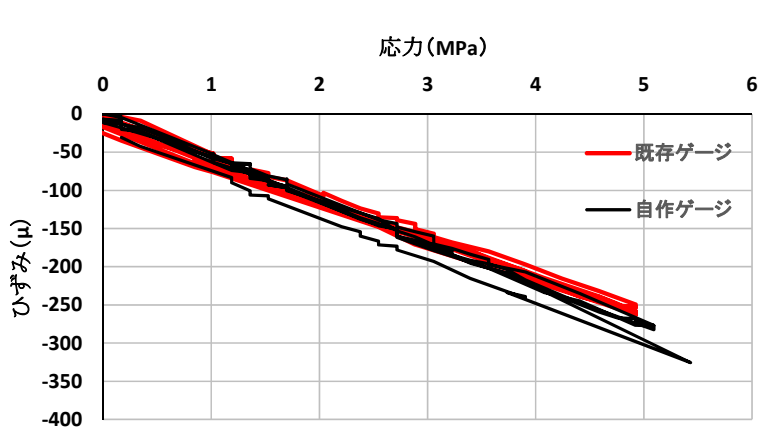

図-4 繰返し載荷試験結果

表-3 供試体パラメータ

\begin{tabular}{|c|c|c|}
\hline 名称 & W/C (\%) & 空気量 (\%) \\
\hline StA & 50 & 5.4 \\
\hline StB & 50 & 1.3 \\
\hline StC & 65 & 3.4 \\
\hline
\end{tabular}

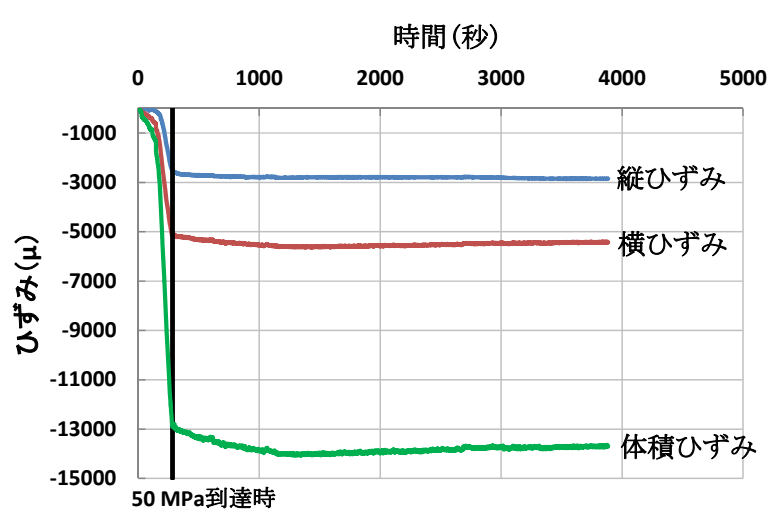

図-5 縦ひずみ，横ひずみ，体積ひずみの代表図

$e=\left[\pi\left\{r\left(1-\varepsilon^{\prime}\right)\right\}^{2}\{t(1-\varepsilon)\}-\pi r^{2} t\right] / \pi r^{2} t$

ここに, $e:$ 体積ひずみ, $r$ 供試体半径, $t$ : 供試体高 さ， $\varepsilon:$ 縦ひずみ, $\varepsilon^{\prime}:$ 横ひずみ，である.

\section{(3) 実験結果}

図-5に水圧作用中の縦ひずみ，横ひずみ，体積ひずみ の経時変化の代表図を示す。ひずみは収縮方向を負とし た. 図中の黒線は水圧が $50 \mathrm{MPa}$ に到達した時間を示す. 図-5から縦ひずみ, 横ひずみ, 体積ひずみともに, $50 \mathrm{MPa}$ 到達までは収縮方向に急激に大きくなり, $50 \mathrm{MPa}$ 到達後 は変化量が減少寸ることが分かる. なお, StA-2, StB-6, StC-1, StC-2 はモールドゲージの不良, 実験中の操作ミ スが生じたため, 以後の実験結果からは除外する. 


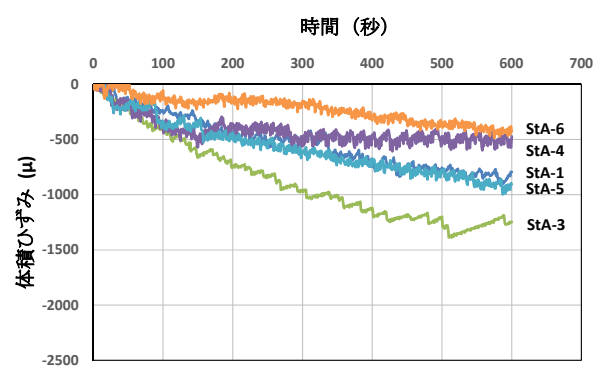

(1) StA

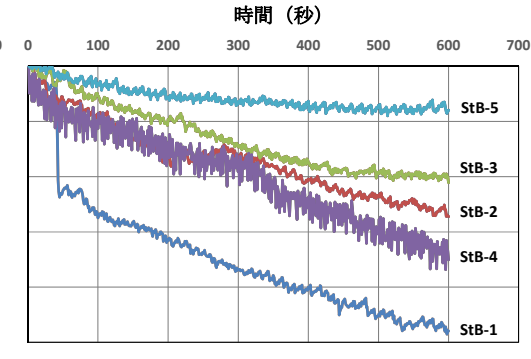

(2) $\mathrm{StB}$

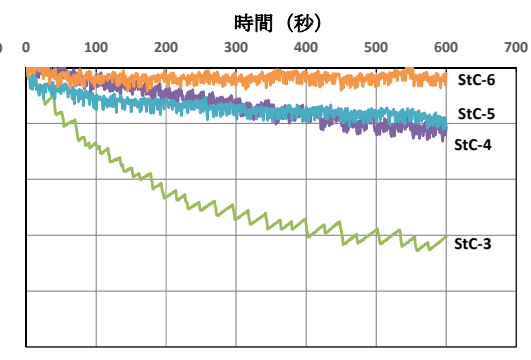

(3) $\mathrm{StC}$

図-6 体積ひずみ変化（0 分～10 分）

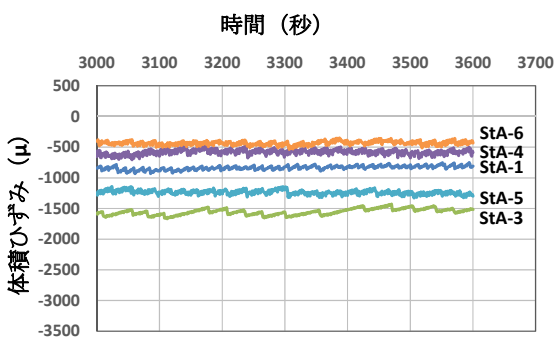

(1) StA
時間（秒）

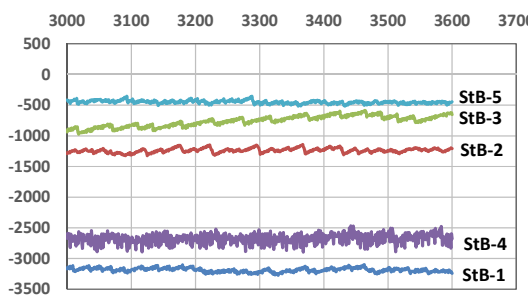

(2) $\mathrm{StB}$
時間（秒）

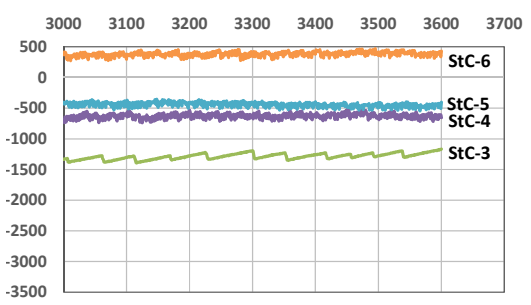

(3) StC

図-7＼cjkstart体積ひずみ変化（50 分～60 分）

図-6に $50 \mathrm{MPa}$ の水圧の作用開始後の 10 分間（0 分 から 10 分）での体積ひずみ変化を示す. 図-6 から体積 ひずみは水圧が $50 \mathrm{MPa}$ 到達後から収縮方向に引き続き 大きくなった後，次第に変化量が減少していくという結 果が得られた. StA と StB を比較すると, 同水セメント 比下では空気量が少ないほど $50 \mathrm{MPa}$ の水圧作用直後の 体積ひずみの収縮方向への増加量が大きくなるという傾 向が得られた. これは，モルタルの透水性の違いによる ものと推察される. 空気量が多い場合, 多量の空隙を介 して浸透した水が内部で連続的に繋がることで，供試体 内部での水分移動の自由度が増し，供試体に作用する外 部水圧のうち, 水分移動に作用する割合が大きく, モル タル骨格に作用する割合が少なくなると推察される。逆 に，空気量が少ない場合，空陌が少量のため，浸透した 水が内部で連続的に繋がらず，供試体内部での水分移動 の自由度が低くなるため, 供試体に作用する外部水圧の うち，モルタル骨格に作用する割合が高くなるため，体 積ひずみが収縮方向に大きく増加したと推察される.

図-7 に測定終了前の 10 分間（50 分から 60 分）での 体積ひずみをそれぞれ示す，図-7 から $50 \mathrm{MPa}$ の水圧を 作用させ， 1 時間静置した供試体の体積ひずみの変化は ごく微小であるといら結果が得られた. $50 \mathrm{MPa}$ の水圧下 に静置されたときの挙動を詳細に検討するため, 50 分〜 60 分での体積ひずみ変化 (図-7) の各供試体での体積ひ ずみ変化を線形近似し, 各々の近似直線の傾きを算出し た. 図-8 に近似直線の傾きを表すグラフを示す.なお, 変化量は膨張方向を正，収縮方向を負とした.

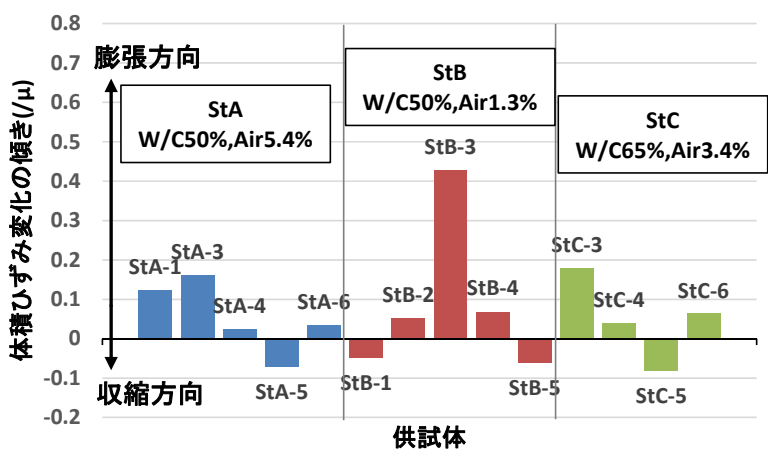

図-8 近似直線の傾き

図-8から全供試体のうち, 膨張方向への傾きを示した のは10 体，収縮方向への傾きを示したのは 4 体であっ た. 各傾きの大きさに着目すると, 収縮方向への傾きの 大きさが膨張方向への傾きの大きさを卓越してはいなか った，そのため，図-6，図-7から，50MPa下での体積ひ ずみは初期に収縮方向に増加した後, 傾きが漸減し, 収 縮方向へのピークをとった後，傾きは微小ではあるもの の, 膨張方向に変化する傾向があるという結果が得られ た. 既往研究で井之上ら 4)は円柱供試体の側面に持続的 に水圧を直接作用させたところ，軸方向への引張ひずみ と周方向への圧縮ひずみの回復現象を観測している. 井 之上ら 4)は一定側圧下での軸方向之周方向への膨張傾向 を水圧作用により浸透した水による間隙水圧が供試体を 押し広げたためと結論付けている. ゴムスリーブを巻く ことで水の浸透を排した供試体では一定側圧下での間隙 
水圧の発生も膨張の傾向も得られていないこともその論 拠の 1 つに挙げられる. 本実験で見られた, $50 \mathrm{MPa}$ 下で の体積ひずみの膨張傾向はこの既往研究で見られた現象 と似た現象であると推察される。本研究では時間単位で の変化を明らかにしたが，月単位や年単位での体積ひず み挙動についても今後も詳細な検討が必要である.

\section{4. まとめ}

本研究では，海底資源の掘削に用いる洋上プラットフ オームの基礎部などの深海部においてコンクリートを用 いることを想定し，基礎検討として海底資源が存在する とされる最高水深である $5000 \mathrm{~m}$ での水圧 $50 \mathrm{MPa}$ をセメ ントペーストやモルタルに作用させ，破壊形状，破壊進 展，水圧下での体積ひずみ変化を検討した.

破壊形状について，セメントペーストでの実験結果か ら, 空気量の多寡によりひび割れの規模が異なり, 空気 量が多いほどひび割れは広範囲で発生した。破壊は供試 体表面を剥離しつつ進展し，破壊面は円球状を呈した.

破壊の進展の度合いについて，セメントペーストでの 実験結果から，水セメント比の大小によりひび割れ発生 時の加圧回数が異なった. 水セメント比が大きいほどひ び割れが発生しづらいという傾向が得られた。

水圧下での体積ひずタ変化について，モルタルでの実 験結果から, $50 \mathrm{MPa}$ の水圧の作用直後に体積ひずみは収 縮方向に増加し，時間経過に伴い変化量は漸减した。水 圧作用初期の収縮方向への体積ひずみ増加は空気量の少 ない供試体で顕著であった。体積ひずみは変化量が漸減 した後，膨張方向に転じるという傾向が得られた.

本研究により, 微細空隙内での水の粘性挙動が高水圧 下での破壊挙動において支配的であると共に，水セメン 卜比や空気量といった内部空隙に関するパラメータが破 壊挙動に明確な影響を及ぼすことが示唆された。コンク リートは多孔質材料であることから，本研究での結果と 類似する結果を得られると推察される.

\section{5. 今後の展望}

本研究で得られた空隙と高水圧作用による破壊挙動と の関連性に関する知見を基に，破壊挙動に影響を及ぼす 要因を検討していく必要がある. 特に空隙構造は空隙の 径，分布，連結といった要因も考えられるため，これら は今後の検討課題となる。 また，本研究では高水圧加力 装置の容積に制限があるためコンクリート供試体を用い なかったが，今後は，コンクリートでも高水圧作用の実 験を行っていく必要がある.

\section{参考文献}

1) 文部科学省・総務省 : 次世代海洋資源調査システムの開発 資料, 【平成 26 年度科学技術重要施策アクションプラン】, pp.3, 2013.12

2) 木村健, 劉兆涛, 一八瀬䝼幸，大下英吉 : コンクリートの 力学的特性に及ぼす微細空隙内部の水圧性状に関する研 究, コンクリート工学年次論文集, Vol.24, No.1, pp.291-296, 2002

3) 齊藤俊一, 清水喜博, 大下英吉 : 三軸応力状態下における コンクリートのクリープと間隙水圧挙動の相関性に関す る研究, コンクリート工学年次論文集, Vol.22, No.2, pp.541546, 2000

4) 井之上尚史, 梨木義春, 大下英吉 : 水圧作用下におけるコ ンクリートのクリープ挙動に関する実験的研究，コンクリ 一ト工学年次論文集, Vol.21, No.2, pp.793-798, 1999

5) 経済産業省・資源エネルギー庁 : 海洋エネルギー・鉱物資 源開発計画, pp.5-35, 2013.12

6) 坂田昇, 菅俣匠, 林大介, 橋本学 : コンクリートの気泡組 織と而凍害性の関係に関する考察，コンクリート工学論文 集，第 23 巻第 1 号, pp.35-47, 2012.1

7) 渡嘉敷勝, 森充広, 増川晋: CA 法を用いた多孔質体中の毛 管浸透モデル, コンクリート工学年次論文集, Vol.27, No.1, pp.583-588, 2005

8) 平井圭, 中村光, 檜貝勇 : コンクリートの圧縮破壊領域の 推定に関する実験的研究, コンクリート工学年次論文集, Vol.17, No.2, pp.339-344, 1995

\section{A FUNDAMENTAL RESEARCH ON FRACTURE BEHAVIOR OF CONCRETE UNDER HIGH WATER PRESSURE}

\section{Takashi HORI, Nobuhiro CHIJIWA and Mitsuyasu IWANAMI}

Recently, seabed resources development is focused. Concrete is one of the materials to construct sea platform to mine seabed resources. However, the knowledge is not enough to use concrete under high water pressure. So this research aims to verifying the applicability of concrete under high water pressure. It was shown that the difference in pore structure due to the difference in water-cement ratio or air content influenced the strain change and fracture behavior of cement paste and mortar specimens under high water pressure. 